\title{
Ébola: Corta y reciente historia de un joven virus
}

\author{
WALTER LEDERMANN D.
}

\author{
Ebola: brief and recent history of a young virus
}

Un reciente brote de alta letalidad en el continente africano puso en el primer plano de la noticia al virus Ébola, y todos los infectólogos nacionales corrimos a los textos en busca de información, pues la historia del virus es tan breve, que no había dejado huella en nuestra memoria. En muchos escritos el Ébola aparece citado junto a su primo hermano el virus Marburg, de manera que es inevitable iniciar la historia con éste.

En Agosto de 1967, llegó a Europa desde Uganda una partida de monos de la especie Cercopithecus aethiops (el green monkey de la literatura inglesa) destinados a laboratorios de Alemania y Yugoeslavia. A los pocos días una extraña enfermedad comenzó a presentarse entre el personal encargado de remover los desechos de los animales, principalmente en dos laboratorios alemanes, con algunos casos también en la ex-Yugoeslavia. Treinta personas fueron afectadas en el plazo de dos meses, falleciendo siete de ellas (23\% de letalidad). La enfermedad empezaba con fiebre, cefalea, mialgias y malestar, a lo cual seguía inyección conjuntival, fotofobia y un exantema generalizado. Otros hallazgos comunes fueron bradicardia, diarrea, oliguria e ictericia leve. Entre los exámenes de laboratorio destacaban la elevación de las transaminasas, una fuerte leucopenia con linfocitosis relativa y trombocitopenia significativa. Al menos en cinco casos secundarios, la enfermedad fue adquirida por contacto con enfermos que se habían infectado, a su vez, por contaminación con sangre o tejidos de monos: dos médicos, una enfermera, un estudiante de medicina y un asistente de autopsia. Esto hizo que los laboratorios alemanes encargados de investigar la etiología de este brote fueran muy cautelosos en el manejo de las muestras, a tal punto de llegar a la decisión de mandarla fuera del país, a un laboratorio especializado en tareas difíciles. Existe en Porton, Inglaterra, un laboratorio que es experto en trabajar muestras peligrosas, para lo cual dispone de excelentes condiciones de seguridad: el Microbiological Research Establishment. Allí un equipo encabezado por C.B. Gordon Smith hizo las investigaciones que llevarían al aislamiento del agente etiológico.

Se enviaron a Porton muestras de sangre total de los pacientes en diferentes etapas de la enfermedad, suero de otros cuatro casos en fase aguda y algunos órganos obtenidos en la autopsia de uno de los afectados: hígado, bazo, riñón, cerebro y ganglios. Todo este material se trabajó en cabinas de seguri- dad especialmente diseñadas, salvo para algunos procesos, durante los cuales el personal tuvo entonces que usar trajes protectores y "respiradores biológicos". Los experimentos con animales también se hicieron en piezas especiales, de las cuales se extraía el aire a través de filtros individuales.

Se inocularon 18 cobayos, sacrificados a distintas alturas de su enfermedad, encontrándose en su necropsia gran esplenomegalia, hemorragias renales, consolidaciones pulmonares con o sin efusión pleural y algunas alteraciones hepáticas. El informe preliminar en el Lancet del 25 de noviembre del mismo año 1967 dice que "aún no es posible llegar a una conclusión definitiva”, pero que las acumulaciones citoplasmáticas encontradas en el hígado son muy similares en forma y tinción a Rickettsia o a organismos del grupo psitacosis-linfogranuloma (hoy Chlamydia). Tres años de trabajo se necesitarían hasta llegar a establecer la identidad virológica de este agente y ubicarlo en la familia Filoviridae. En ese momento se cometió la injusticia de llamarlo virus de Marburg, en honor a la ciudad más afectada por este accidente de laboratorio y no virus Uganda, su lugar de origen. Este error no volvería a cometerse con el virus Ébola.

Ahora bien, como el amor no podía estar ausente en esta historia, hubo un sexto caso secundario, que explica la discrepancia entre los treinta que alcanzó a reunir la comunicación preliminar y los treinta y uno que figuran en todos los textos: se produjo varias semanas después y el virus se aisló del semen del hechor.

Pasarían ocho años hasta la reaparición del virus de Marburg. En 1975 un joven viajero, luego de recorrer extensamente Rhodesia, debió internarse en un hospital de Sudáfrica, donde murió víctima del Marburg. Este minibrote se extendió a un compañero de viaje y a una enfermera, quienes felizmente sobrevivieron. Un año después, casos similares se presentaron casi simultáneamente de dos regiones del continente africano. El primer episodio, cronológicamente, afectó a 318 personas en la zona de Bumba, en el norte de Zaire, con la espantosa letalidad de $90 \%$, en tanto que el segundo se presentó en la zona sur de Sudán, abarcando las áreas de Nzara, Maridi y Lirangu, con un total de 250 casos y una letalidad promedio de apenas $60 \%$, aunque en la región más afectada llegó a 80\%. La mayor diseminación del virus se produjo en forma intrahospitalaria, por contacto persona a persona y por la reutilización 
de agujas contaminadas, provocando pánico entre el personal. Las muestras se enviaron a laboratorios de alta seguridad en Estados Unidos, en Bélgica y en Inglaterra (Porton, por supuesto), coincidiendo los tres en que el virus era morfológicamente igual al Marburg, esto es, un Filoviridae, pero serológicamente distinto. Nótese que en los países civilizados hay serotecas, donde se guardan todos los sueros de pacientes afectados por enfermedades misteriosas, de manera que la comparación se pudo hacer con los obtenidos del epsiodio de Marburg. La conclusión, final fue que se estaba ante un nuevo virus y que su bautizo era inminente.

Esta vez se quiso hacer justicia y hubo una reunión en busca de consenso, en la cual estaban presentes el Dr. E.T. Bowen, de Porton, quien figura en todas las publicaciones originales de esta historia, y el profesor S.R. Pattyn, del Institute of Tropical Medicine de Antwerp. Se decidió no usar nombres de países o ciudades, como una muestra de deferencia hacia los países afectados por los brotes, puesto que no había certeza sobre la fuente original del virus y, para no herir nacionalismos, se utilizó el nombre de un pequeño río de Zaire, que fluye hacia el oeste, al norte de Yambuku. De este poblado de Yambuku provenía el infortunado paciente del cual se hizo el primer aislamiento del virus.

Hubo intentos por relacionar el virus de Ébola con los murciélagos, ya que tanto este brote original de 1976, así como el siguiente de 1979, se iniciaron en trabajadores sudaneses de una fábrica de algodón, de cuyo techo colgaban miles de estos animales. Hay al menos otros dos episodios, en 1980 y 1987, cuando enfermaron personas que entraron a una misma caverna con murciélagos en Kenya oriental. Los intentos fracasaron, porque hasta ahora no se han aislado de estos odiosos mamíferos volantes ni el Marburg ni el Ébola.

El virus de Ébola no esperó mucho para tomar venganza de los investigadores del laboratorio de alta seguridad de Porton. El 5 de noviembre de 1976, en circunstancias que uno de sus científicos estaba trabajando en un homogenizado del hígado extraído a un cobayo inoculado con Ébola, se pinchó accidentalmente un pulgar a través de su guante de alta seguridad. "De acuerdo al protocolo estándar de seguridad, se quitó inmediatamente el guante y sumergió su pulgar en la solución de hipoclorito, sacudiéndolo luego vigorosamente". El dedo no sangró. Una cuidadosa revisión con lupa no mostró ni la menor lesión puntiforme. El desdichado investigador quedó en observación durante cinco largos días y al sexto enfermó. Su cuadro clínico fue cuidadosamente observado y su detallada exposición apareció en el British Medical Journal. Se le tomaron todas las muestras imaginables, incluyendo semen, y de todas partes se aisló el virus, identificado por microscopia electrónica. Se pidió de inmediato ayuda al equipo médico de la OMS, que aún estaba estudiando el brote en Sudán, y a la Comisión Internacional que hacía lo mismo en Zaire, y de este país se trajo suero de convaleciente y se le puso endovenoso. Además, se le inyectó interferón humano, preparado estimulando linfocitos periféricos con virus Sendai in vitro. Al décimo segundo día de enfermedad, el 23 de noviembre, se estimó salvado, pero la recuperación total de sus parámetros de laboratorio sólo se concretó el 8 de febrero, tres meses después del inicio. Perdió una considerable cantidad de cabello. Cuatro de los cinco médicos que lo atendían desarrollaron un flu-like illness, con algunos síntomas gastrointestinales ( no era para menos), mejorando luego de dos a tres días. Ni en ellos ni en el resto del equipo médico, ni en el de enfermería, se detectó serología positiva para el Ébola. Un punto curioso fue la determinación del término del aislamiento del paciente: se hicieron controles virológicos semanales, decidiendo que el aislamiento cesaría cuando tuviera tres sets negativos de cultivos de faringe, sangre, orina y deposiciones. Cuando se alcanzó este punto, sin embargo, el virus seguía apareciendo en el semen (se negativizaría el día número 76), pero el equipo médico consideró que no era causal para mantenerlo en cuarentena, especialmente cuando el paciente fully apreciated the implications.

Y, como esta vez no hubo casos secundarios, el honor de Porton quedó a salvo.

\section{Bibliografía}

1.- Gordon Smith C E, Simpson D I H, Bowen E T W. Fatal human disease from vervet monkeys. Preliminary communication. Lancet 1967, November 25: 119.

2.- Bowen E T W, Simpson D I H, Bright W F et al. Vervet monkey disease: Studies on some physical and chemical properties of the causative agent. Br J Exp Path 1969; 50: 400.

3.- Johnson K M, Webb P A, Lange J V, Murphy F A. Isolation and partial characterisation of a new virus causing acute haemorragic fever in Zaire. Lancet 1977, March 2; 569.

4.- Bowen E T W, Platt G S, Lloyd G et al. Viral haemorragic fever in southern Sudan and northern Zaire. Lancet 1977, March 2; 571.

5.- Gear J S S et al.Outbreak of Marburg virus disease in Johannesburg. Br Med J 1975; 4: 489.

6.- Edmond R T D, Brandon Evans, Bowen E T W, Lloyd G. A case of Ebola virus infection. Br Med J 1977, 2: 541.

7.- Report of International Comission. Ebola haemorragic fever in Zaire. Bull WHO 1978, 56: 271.

8.- WHO International Study Team in Sudan (1976). Ebola haemorragic fever in Sudan. Bull WHO 1978, 56: 247. 


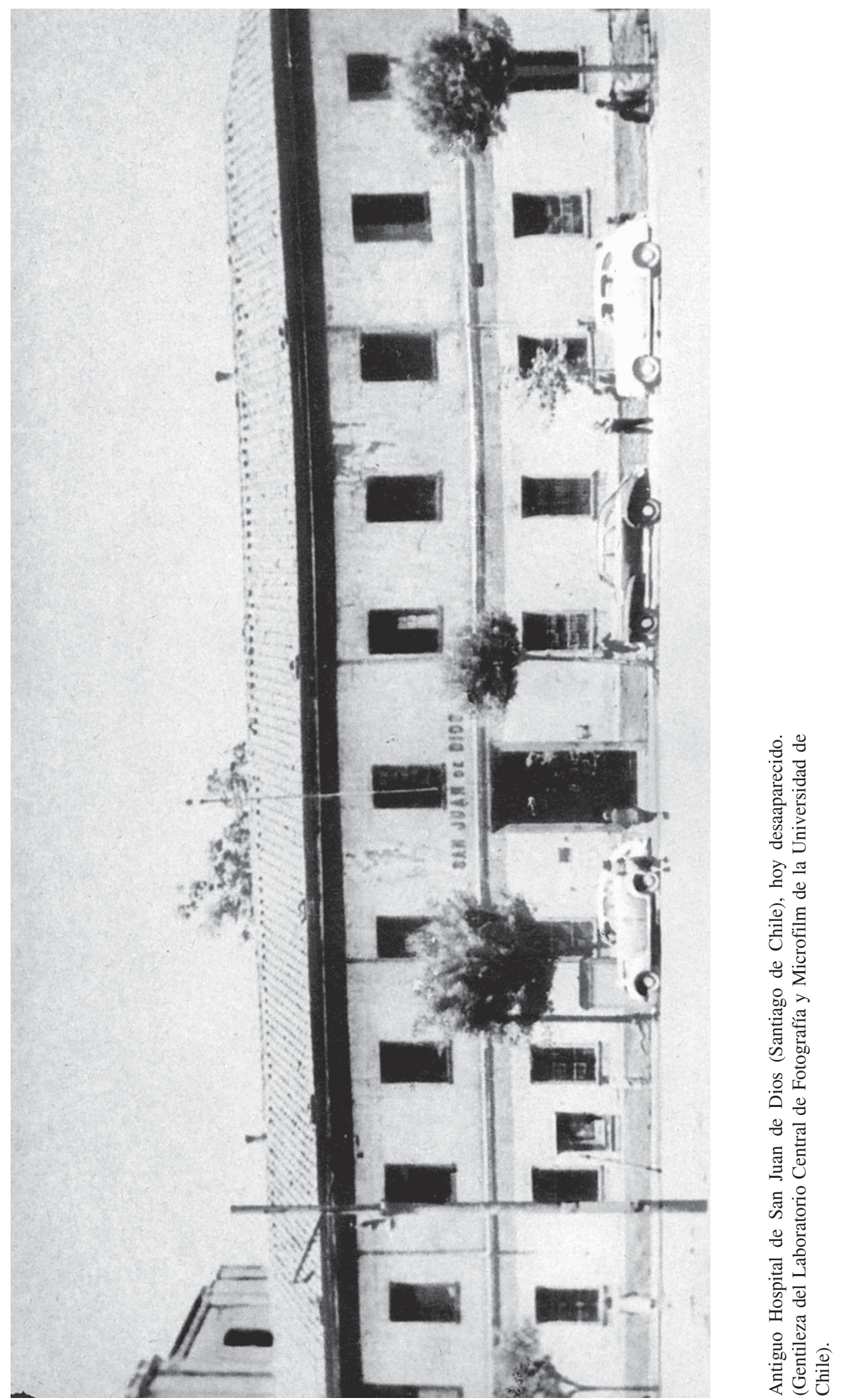

